\title{
The Assessment of Soil Quality Index for Paddy Fields with Indicator Biology in Jatipurno Districts, Wonogirl
}

\author{
Supriyadi ${ }^{1}$, Widyatmani Sih Dewi ${ }^{1}$, Desmiasari Nugrahani ${ }^{2}$, Adila Azza Rahmah ${ }^{2}$, Haryuni $^{3} \&$ Sumani $^{1}$ \\ ${ }^{1}$ Department of Soil Science, Faculty of Agriculture, Sebelas Maret University, Surakarta, Indonesia. \\ ${ }^{2}$ Student of Department of Soil Science, Faculty of Agriculture, Sebelas Maret University, Surakarta, Indonesia. \\ ${ }^{3}$ Department of Agroteknology Faculty of Agriculture, Universitas Tunas Pembangunan Surakarta, Indonesia. \\ Correspondence: Supriyadi, Department of Soil Science, Faculty of Agriculture, Sebelas Maret University, Jl. Ir. \\ Sutami 36A Surakarta 57126, Indonesia. E-mail: supriyadi_uns@yahoo.com
}

Received: October 7, 2019

Accepted: December 5, 2019

Online Published: December 26, 2019

doi:10.5539/mas.v14n1p20

URL: https://doi.org/10.5539/mas.v14n1p20

\begin{abstract}
Increased rice needs in an extensive use of paddy fields in the Jatipurno, Wonogiri. Managing rice fields can reduce soil quality. Proper management can improve soil quality, Jatipurno has management such as organic, semi-organic and inorganic paddy field management which have a real effect on soil quality. Assessment of soil quality is measured by physical, chemical and biological indicators, where each factor has a different effect. The chemical indicators are often used as the main indicators for determining soil quality, whereas every parameter has the opportunity to be the main indicator. So, biological indicators can play indicators. The main indicators are obtained from the correlation test ( $\mathrm{p}$-values $\leq 0,05-<0,01)$ and Principal Component Analysis with high value, eigenvalues $>1$ have the potential to be used as Minimum Data Sets. The result is biological can be able to use as the Minimum Data Set such as microbial carbon biomass, respiration, and total bacterial colonies. The Soil Quality Index (SQI) of various paddy management practices shows very low to low soil quality values. The management of organic rice systems shows better Soil Quality Index with a score of 0,20 compared to other management. The practice of organic rice management shows that it can improve soil quality.
\end{abstract}

Keywords: indicator biology, minimum data set, soil quality index, principal component analysis

\section{Introduction}

Increasing food needs give rise to the wide paddy fields to meet food consumption (Liu et al., 2014). Paddy field intensive management results in changes in soil quality that are low. There needs to be appropriate management to improve soil quality. Soil quality provides physical, chemical, and biological requirements for soul productivity, food quality and health, environmental safety of the animal and human plants (Doran and Parkin, 1994 ; Dengiz O., 2019).

Jatipurno Subdistrict is one of the sub-district in Wonogiri Regency. The use of rice fields in Jatipurno has an area of around 1322.14 ha or $25.20 \%$ BPS Wonogiri (2018) of the total land-use area. Based on data from the Research and Development Agency of the Ministry of Agriculture, 3,250 million ha of rice containing organic matter is less than $2 \%$ (Sitepu, Anas, and Djuniwati, 2017). This fact proves that rice fields have low fertility and soil quality. The long-term use of rice fields in Merauke has a low Soil Quality Index (SQI) of 0.33 (Supriyadi et al., 2017). Improper management of paddy fields use of inorganic fertilizers results in environmental pollution making (Zhao et al., 2016 ; Oladele., 2017) the Soil Quality Index low.

Organic farming systems can improve the soil quality of Sukristiyonobowo, Purwanto, B. H. and Husen, E., (2015) and the environment, especially about to with concerning biological activities in the soil, Mangunharjo village, Jatipurno, which has organic, semi-organic and inorganic management. Evaluation of soil quality in various practices in managing paddy fields is still small. The value of organic and inorganic rice soil quality in the Susukan area has a Soil Quality Index (SQI) value of 0.42 and 0.3 in the medium category (Mustikaningrum et al. 2018). Soil Quality Index (SQI) can be used for soil quality assessment (Doran and Zeiss, 2000; Larson et al. 1994) and SQI method easy in use and flexible when used with measurements (Reeves, D. W., 1997 ; Marzaioli R, D'Ascoli R, De Pascale RA, and Rutigliano FA., 2010 ; Fernandes JC, Gamero CA, and Rodrigues JGLMirás-Avalos, J. M., 2011 ; Liu Z, Zhou W, Shen J, Li S, and Ai C, 2014 ; Li P, Zhang T, Wang X, 
and Yu D., 2013). However, most calculations of soil quality are determined by chemical indicators. Even though each indicator has the same opportunity to be used as the main indicator to determine the soil quality. Indicators that are generally used as indicators of soil quality such as aggregate stability, specific gravity, $\mathrm{pH}$, salinity, CEC, microbial biomass and respiration (Martinez-Salgado, Gutierrez-Romero, V. Jannsens, and Ortega-Blu, 2010).

The main problems with the implementation of soil quality indices are the classification of organisms at the specifies level, which needs to be sorted out by specialists and is time consuming. The species identification of soil organisms must be easy Breure A.M., Mulder C., Römbke J., and Ruf A., (2005) in the biomonitoring program of soil quality. The nature of organic matter is related to the availability of $\mathrm{C}$ and microbial biomass. These factors make biological indicators have potential as the main indicator. Biological activities are considered difficult to assess even though they have an important role in the characteristics of soil (Reeves, D.W.,1997). Naturally, soil organisms have an important role to play in managing and improving soil quality in a sustainable manner (BPS Wonogiri 2018). Appropriate management will have an impact on the safety of organisms in the soil Kouamé et al. (2004) that can improve soil quality (Chan et al. 2007). The transition of land from natural forest to intensive land use results in soil fertility Dinesh et al. (2003) and soil biology index (Islam et al. 2000). There is a need for research on the biological parameter of soil as a good indicator of Doran and Zeiss, (2000) the main key to assessing soil quality (Acosta-Martinez et al. 2007). The study of these problems is still small so there is a need to develop how much influence biological indicators determine soil quality, especially in the use of paddy fields in the Jatipurno area, Wonogiri. This research is expected to provide appropriate solutions regarding good soil quality, especially the influence of biological indicators on the process of increasing biological activity to improve the quality of paddy fields and increase rice production.

\subsection{Introduce the Problem}

The study is intending to adder following questions about :

How does the influence of agricultural management in paddy fields on land quality assessment mainly seen from biological factors?

\subsection{Target and Inquires of Study}

The study goal is to probe the assessment of soil quality index for paddy fields with indicator biology in Jatipurno Districts, Wonogiri through the following questions :

Question 1: What are biological indicators as the main components that determine the Soil Quality Index (SQI)?

Question 2 : Is the quality of organic paddy soil better than semi-organic and inorganic paddy fields?

\subsection{Importance of the Study}

It is hoped that the following entities will benefit from the results of this study :

- Paddy fields in Jatipurno Districts: evaluating the influence of biological indicators as the main component to determine the value of paddy soil quality in Mangunharjo Village, Jatipurno, Wonogiri

- Researchers: assess the best quality of paddy soil in Mangunharjo Village, Jatipurno, Wonogiri

\subsection{Definition}

1. Paddy fields are the largest form of agricultural land use in Indonesia as a result of human activities (anthropogenic) which is influenced by the making or printing of rice fields and management or cultivation methods which are used as the main resources for producing basic foodstuffs such as rice. (Subgyayono, 2001).

2. Soil quality is the capacity of the functioning of a soil (Doran, J. W. and Parkin, T. B., 1994; Karlen et al., 1997; Shukla et al., 2006) is a collection of various indicators both physical, chemical and biological (Reeves 1997).

3. The Soil Quality Index as a tool used to determine sustainable soil management (Supriyadi et al, 2017)

4. Biological indicators have a cause and effect with some soil characteristics, especially in population and soil biota activity, so biology indicators are used as indicators of soil quality (Hadi et al. 2014).

\subsection{Limitation}

The study is limited in the following:

Place : Paddy fields with the management system organic, semi-organic and inorganic in Jatipurno District.

\subsection{Previous Related Research}

Some of the relevant studies are presented below for benefiting from their methodological procedures and 
theoretical literature they have included. They have been chronologically arranged from the oldest to latest :

A study by Gulser (2004) entitled " A Comparison of Some Physical and Chemical Soil Quality Indicators Influenced by Different Crop Science ", aimed to determine the changes in some physical and chemical soil quality indicators of clay soil under six different crop species in comparison to the fallow plots.

A study by Riches D, Porter I.J., Oliver D.P., Bramly R. G. V., Rawnsley B., Edwards J., and White R.E. (2013) entitled "Review: soil biological properties as indicators of soil quality in Australian viticulture", aimed to recommendations for the inclusion of biological indicators as a component of an MDS for viticulture, based on their suitability, ease of measurement and current availability to the industry.

A study by Nwaichi E.O., and Chuku L.C entitled " Biological Soil Quality Indicators and Conditioners in a Plant-Assisted Remediation of Crude Oil Polluted Farmland", aimed to evaluate the possible effect of management practices on vital and relevant enzyme activities in petroleum polluted soil with a four-factorphytoremediation recovery attempts.

A study by Martinez-Salgado M,M, Gutiérrez-Romero, V., Jannsens, M. And Ortega-Blu, R. (2019) entitled "Biological soil quality indicators: a review" aimed to soil quality acquires an important dimension related to the strategies for conservation, health, good agricultural practices, and agroecosystems sustainability.

A Study by Supriyadi, S, Purwanto, Sarijan A. Mekiuw Y., Usiatik R., Prahesti R. R (2017) entitled "The Assessment of Soil Quality at Paddy Fields In Merauke, Indonesia"aimed to investigate any condition which has a correlation between the indicators and soil quality status of old and new paddy fields through the SQI.

A study by Mustikaningrum, I. A., Supriyadi, Herawati A., Purwanto P., Sumani S. (2018) entitled "Soil quality assessment in organic and non-organic paddy fields in Susukan, Indonesia" aimed to compare the soil quality on organic and non-organic paddy fields.

\subsection{What Distigueshes this Study from Previous Studies}

The previous study about the Soil Quality Index, which assessed funding for soil quality in Jatipurno District, prioritized biological indicators as the MDS that was the most difficult to achieve in the study of soil quality.

\section{Method}

\subsection{Study Area}

The study conducted at the paddy field sites of Mangunjarjo village, Jatipurno district, Wonogiri (fig. 1) (latitude $7^{\circ} 46^{\prime} 52^{\prime \prime} \mathrm{S}$ dan $111^{\circ} 07^{\prime} 06^{\prime}$ ' E. The research conducted in September-October 2018, with altitude $527 \mathrm{~m}$ above sea level. The type of soil in this area is Latosol (Red-brownish). To assess the changes management soil quality, the present study was conducted at the different management of organic paddy fields with the preparation of manure 3-4 tons/ha, semi-organic management with the provision of $1,5-2 \mathrm{~kg} / \mathrm{ha}$ and $65 \mathrm{~kg} / \mathrm{ha}$ of phonska fertilizer and management of inorganic paddy fields with phonska fertilizer of $100-125 \mathrm{~kg} / \mathrm{ha}$. The age of paddy in three management systems is 35-40 days.

\subsection{Soil Sampling}

The research carried out with a field survey using a purposive sampling method (criteria determined by researchers) with 9 sample points three replications. At each site, taking samples using diagonal method five quadrates $(100 \mathrm{~cm})$ and from each management paddy field, soil samples were collected $(0-10 \mathrm{~cm}$ depth) and mixed thoroughly, where there is one determining point then we draw a diagonal line with a distance of $1 \mathrm{~m}$ then composite. Analyses of soil physical and chemical properties were carried out on a composite sample from the selected soil layer. For analysis of soil biological properties, fields moist soil samples were taken in ice boxes, transported to labolatory and stores $+4^{\circ} \mathrm{C}$ till their analysis.

\subsection{Analytical Methods}

Soil analyze methods include physics, chemical and a biological indicator conducted in the laboratory by the method such as soil texture by the piping method, bulk density was determined by the pycnometer method. Potential hydrogen was measured using $\mathrm{pH}$ meter (electrometric method). Total nitrogen was measured by the Kjeldahl method. Organic carbon (OC) was determined based on the Walkey Black rapid titration method. Cation Exchange Capacity (CEC), Base Saturation and Available K were determined based on Ammonium Asetat $1 \mathrm{~N}$ extraction. Exchangeable Aluminium was determined based on the saturation of potassium chloride. Available $\mathrm{P}$ was measured with the Olsen method. Respiration measured by the titrimetric method. Biomass carbon was determined by the fumigation method. Total colony measured by pour plate method. All of these analyses are based on (Balittan 2005). 


\subsection{Soil Quality Assessment}

Soil quality assessment is a three-step process on the basis which the current tool was developed Andrews et al. (2002) such as a selection of the minimum data set (MDS), data normalization and integration of the indicator scores into soil quality index (SQI). That's tool can be applied to the variety of climate, soil type, management practices, and end-user goal. Consistent with data normality we used Pearson's correlation to analyze soil parameters. Soil physical-chemical and biological characteristics measured with Principal Component Analysis where select Principal Components with eigenvalues $>1$ (Andrews et al. 2002; Brejda et al. 2000; Reeves, D. W. 1997) and/or contribution to explaining variability $75 \%$. For each of the PC selected based on the criteria above, identify variables with highly weighted factor loadings. A multivariate procedure such as Principal Component Analysis (PCA) Arekhi et al. (2010) and Loading Plot to get Minimum Data Set (MDS). That analyze to determine the most effective factors with influence on plot distribution, multivariate procedure. The selected data is then followed by Scoring ( $\mathrm{Si}$ ) based on (Chandel et al. 2018). Calculation of soil quality is done by summing the variable scores that have been multiplied by the Weight Index (Wi) Supriyadi el al., (2017) then classified according to Cantu et al. (2009) shown by in (Table 1).the final PCA based MSQI equation is as follows :

$$
\mathrm{MSQI}=\sum_{i=1}^{n} W i S i
$$

where, $\mathrm{Wi}$ is the $\mathrm{PC}$ weighting factor, $\mathrm{S}$ is the indicator score for each variable.

Better soil quality and better performance of soil quality indicators, soil having a higher index score indicates.

Table 1. Soil Quality Index Classification

\begin{tabular}{ccc}
\hline Soil Quality Index & Value & Class \\
\hline Better & $0,80-1$ & 1 \\
Good & $0,60-0,79$ & 2 \\
Moderate & $0,35-0,59$ & 3 \\
Low & $0,20-0,34$ & 4 \\
Very Low & $0-0,19$ & 5 \\
\hline
\end{tabular}




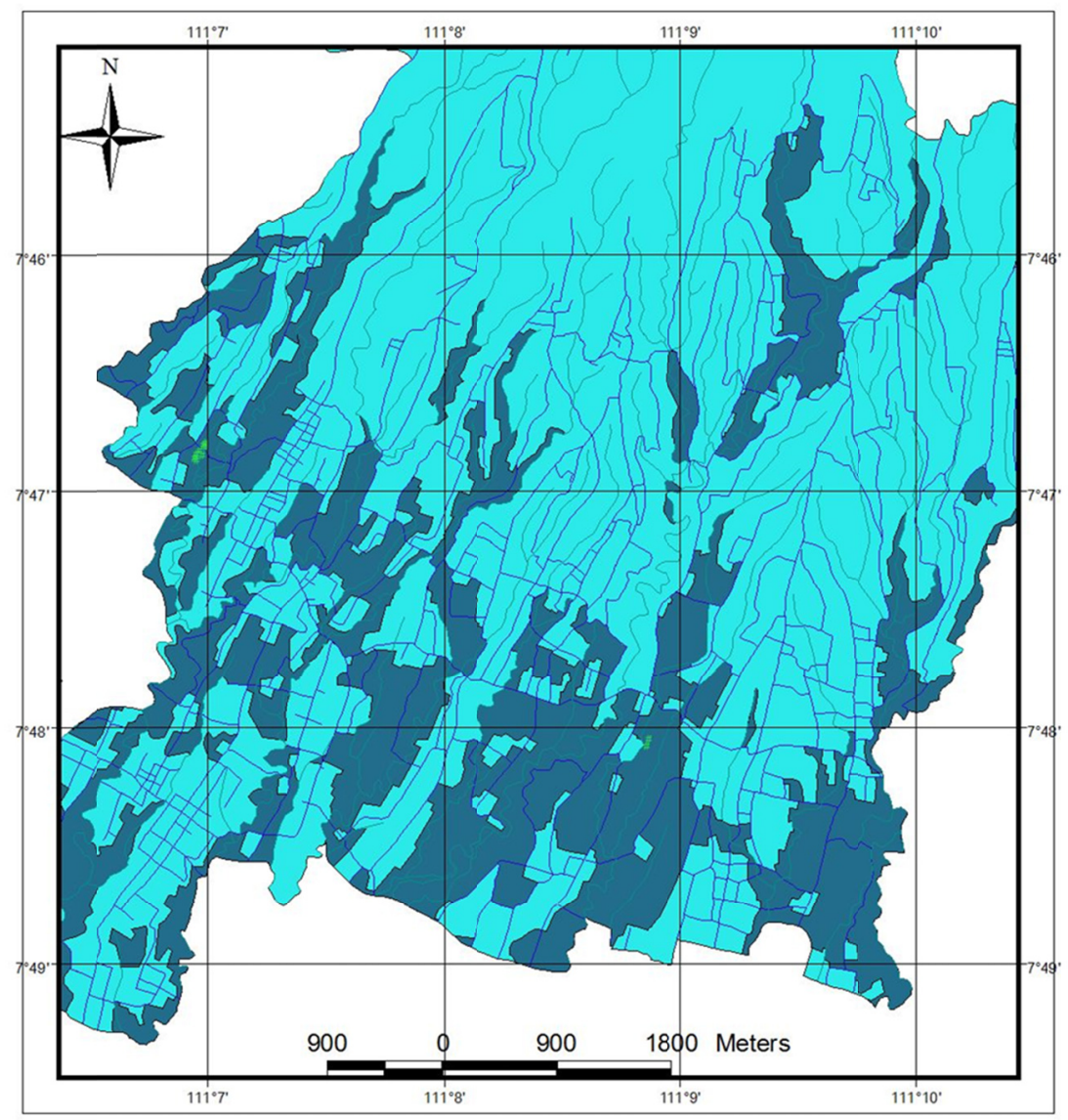

Figure 1. Overlay of map soil sampling

\subsection{Statistical Analysis}

T-test was carried out to compare the means of soil characteristics with respect to each management of paddy fields using a 5\% T-test and if there were significant results it was continued by Duncan test on 5\% levels.. For PCA, regression equations and score functions, Microsoft Excell and Minitab were used.

\section{Results}

\subsection{Characteristic Soil Biology-Chemical-Physics in Three Sites}

Biological, chemical and physical properties have different characteristics depending on the management of the soil. The condition of paddy fields in Jatipurno managed organically has better biological, physical and chemical values compared to semi-organic and inorganic management shown by in (Table 2). Analysis of biological indicators such as total colony, carbon biomass and microbial respiration in the management of organic paddy fields in Mangunharjo, Jatipurno has a higher value than semi-organic and inorganic management. According to research Wahyuni et al. (2016) that giving manure $20 \mathrm{~kg} / \mathrm{ha}$ increases the bacterial population to $105 \mathrm{cfu} / \mathrm{ml}$ and according to Surekha (2013) that microbial respiration has a higher treatment with organic giving. The results of the Pearson correlation test showed that Total Colonies were significantly positively correlated with Carbon Biomass; Respiration; $\mathrm{N}$ total; $\mathrm{P}$ available; $\mathrm{K}$ available; and Organic $\mathrm{C}(\mathrm{r}=0.92 * *, \mathrm{P}$-value $=0 ; \mathrm{r}=0.699$ *, $\mathrm{P}$-value $=0.036 ; \mathrm{r}=0.814^{* *}, \mathrm{P}$-value $=0.008 ; \mathrm{r}=0.886^{* *}, \mathrm{P}$-value $=0.001 ; \mathrm{r}=0.678^{*}, \mathrm{P}$-value $=0.045 ; \mathrm{r}=$ $0.951^{* *}$, P-value $=0$ ) can be seen in Table 2. According to Surekha (2013) between soil respiration, carbon biomass and total microorganism have an association with one another which is determined by the organic matter content.

The value of Cation Exchange Capacity in paddy fields in each system both organic, semi-organic and inorganic has a low CEC value and no significant influence between treatments. Cation exchange capacity is always in line with basic saturation. But the results of CEC analysis with Base Saturation did not correlate significantly. CEC analysis was positively correlated with available $(r=0.766$, $p$-value $=0.016)$ can be seen in Table 2 . because 
the mineralization process would increase K cations. According to Sufardi et al. (2017), high CEC is not always followed by high base saturation because CEC in tropical land does not always describe the number of cations that are absorbed by the soil but describes the cations adsorbed on the colloidal surface.

Table 2. Soil Characteristics, Biological-Chemical-Physical In Three Site

\begin{tabular}{cccc}
\hline Sites & Organic & Semi-organic & Inorganic \\
\hline Variables & Mean & Mean & Mean \\
\hline Total Colony (CFU/gram) & $6.9 \times 105 \mathrm{~b}$ & $1.8 \times 105 \mathrm{a}$ & $1.2 \times 105 \mathrm{a}$ \\
Carbon Biomass (microgram/gram) & $36.21 \pm 7,81 \mathrm{~b}$ & $20.80 \pm 1,93 \mathrm{a}$ & $14.72 \pm 1,46 \mathrm{a}$ \\
Respiration (lbs CO2 m $^{-2}$ hours $^{-1}$ ) & $11.24 \pm 5,50 \mathrm{c}$ & $8.21 \pm 3,94 \mathrm{~b}$ & $4.34 \pm 8,51 \mathrm{a}$ \\
$\mathrm{pH}$ & $6.37 \pm 0,58 \mathrm{~b}$ & $6.27 \pm 0,58 \mathrm{~b}$ & $6.03 \pm 0,12 \mathrm{a}$ \\
Cation Exchange Capacity (CEC) & $14.42 \pm 0,46 \mathrm{~b}$ & $11.94 \pm 0,41 \mathrm{a}$ & $13.30 \pm 1,39 \mathrm{ab}$ \\
(me/100kg) & & & \\
Base Saturation (BS) (\%) & $28.79 \pm 12,37 \mathrm{a}$ & $37.04 \pm 4,71 \mathrm{a}$ & $25.15 \pm 6,92 \mathrm{a}$ \\
Total Nitrogen (\%) & $0.4 \pm 0,17 \mathrm{~b}$ & $0.35 \pm 0,23 \mathrm{a}$ & $0.31 \pm 0,23 \mathrm{a}$ \\
Organic Carbon (\%) & $2.37 \pm 0,57 \mathrm{~b}$ & $1.13 \pm 0,21 \mathrm{a}$ & $0.97 \pm 0,11 \mathrm{a}$ \\
Available P (mg/liter) & $4.41 \pm 0,50 \mathrm{~b}$ & $3.45 \pm 0,61 \mathrm{~b}$ & $3.85 \pm 0,17 \mathrm{ab}$ \\
Available K (mg/liter) & $2.93 \pm 0,75 \mathrm{~b}$ & $1.42 \pm 0,18 \mathrm{a}$ & $2.26 \pm 0,41 \mathrm{ab}$ \\
Exchangeable Alumunium (\%) & $1.79 \pm 0,62 \mathrm{a}$ & $2.62 \pm 0,72 \mathrm{a}$ & $3.06 \pm 1,23 \mathrm{a}$ \\
Bulk Density (gram/cm-3) & $2.15 \pm 0,13 \mathrm{a}$ & $2.24 \pm 0,61 \mathrm{a}$ & $2.09 \pm 0,13 \mathrm{a}$ \\
\hline
\end{tabular}

Description: $\mathrm{CEC}=$ Cation Exchange Capacity; BS = Base Saturation, Values are mean + - standard error $(\mathrm{n}=27)$, different lowercase letters represent difference significant $(\mathrm{P}<0.05)$.

The available value of organic management has a higher value compared to semi-organic and inorganic management. According to Sufardi et al. (2017) that the addition of organic materials such as rice straw and poultry manure has a high $\mathrm{K}$ content of $592 \mathrm{~kg} / \mathrm{ha}$ of organic systems, and inorganic systems $548 \mathrm{~kg} / \mathrm{ha}$ to increase $\mathrm{K}$ availability. Correlation test results that Kedia is available have a positive correlation significantly with Organic Carbon, Total Colony and Carbon Biomass $(\mathrm{r}=0.732, \mathrm{p}=0.25 ; \mathrm{r}=0.678, \mathrm{p}=0.045 ; \mathrm{r}=0.666, \mathrm{p}=$ 0.05 ) can be seen in Table 3.

The Mangunharjo rice field has Organic Carbon significantly due to management both organically, semi-organically and inorganically. Organic Carbon correlation results were correlated with Total Nitrogen, Available, and Available $(\mathrm{r}=0.767, \mathrm{p}=0.016 ; \mathrm{r}=0.933, \mathrm{p}=0 ; \mathrm{r}=0.732, \mathrm{p}=0.025)$ can be seen in Table 2 . Rice fields with organic systems have higher Organic Carbon content compared to other paddy fields. The provision of organic matter in rice fields with long periods will increase the Organic Carbon content in paddy soils (Chen et al. 2018).

The $\mathrm{pH}$ range is about 6.4 in both organic, semi-organic and inorganic rice fields. According to McCauley et al. (2018), soil $\mathrm{pH}$ affects nutrient availability because $\mathrm{H}+$ ions take the place of negative charge on the surface of the soil. The $\mathrm{pH}$ value of 6.4 is classified as slightly acidic or tends to be neutral. Low $\mathrm{pH}$ will result in $\mathrm{Al}$ being mobile (Darlita et al. 2017). The highest available value obtained in organic treatment. By following the study Sari et al. (2017) that there was an increase in P due to the addition of organic matter from $8.93 \mathrm{ppm}$ to 19.56 ppm. 
Table 3. Pearson's correlation coefficient of biological parameters with chemical and physics parameters

\begin{tabular}{cccc}
\hline Variable & Respiration & Biomassa Carbon & Total Colony \\
\hline Respiration (lbs $\mathrm{CO}_{2} \mathrm{~m}^{-2}$ hours $\left.^{-1}\right)$ & - & $0.856^{* *}$ & $0.699^{*}$ \\
Carbon Biomassa (microgram/gram) & $0.856^{* *}$ & - & $0.92^{* *}$ \\
Total Colony $(\mathrm{CFU} / \mathrm{gram})$ & $0.699^{*}$ & $0.92^{* *}$ & - \\
Bulk Density/ (gram cm $\left.{ }^{-3}\right)$ & $0.142 \mathrm{~ns}$ & $0.13 \mathrm{~ns}$ & $-0.11 \mathrm{~ns}$ \\
$\mathrm{pH}(\mathrm{pH} \mathrm{H} \mathrm{O})$ & $0.757^{*}$ & $0.653 \mathrm{~ns}$ & $0.543 \mathrm{~ns}$ \\
Total Nitrogen (\%) & $0.725^{*}$ & $0.807^{* *}$ & $0.814^{* *}$ \\
Organic Carbon (\%) & $0.809^{* *}$ & $0.981^{* *}$ & $0.951^{* *}$ \\
Cation Exchange Capacity (CEC) & $0.368 \mathrm{~ns}$ & $0.561 \mathrm{~ns}$ & $0.521 \mathrm{~ns}$ \\
(me/100kg) & 0.134 & $0.226 \mathrm{~ns}$ & $0.059 \mathrm{~ns}$ \\
Base Saturation (BS) (\%) & $-0.465 \mathrm{~ns}$ & $-0.664 \mathrm{~ns}$ & -0.613 \\
Exchangeable Alumunium (\%) & $0.891^{* *}$ & $0.958^{* *}$ & $0.886^{* *}$ \\
Available P (mg/liter) & $0.277 \mathrm{~ns}$ & $0.666^{*}$ & $0.678^{*}$ \\
Available K (mg/liter) &
\end{tabular}

*Significant $(\mathrm{P}<0.05),{ }^{* *}$ Significant $(\mathrm{P}<0.01), \mathrm{ns}$ : No significant $(\mathrm{n}=27)$.

The weight of the type is related to the congestion of the soil. Bulk density has good balanced macro micro pores for developing microbial processes, root penetration, water retention and so on. According to Primadani et al. (2010) the lower soil density, it will make it easier for the roots to push the soil and break down the soil structure so that it becomes a way of aeration of the soil to hold and bind water and soil nutrients.

\subsection{Soil Quality Index}

Calculation of Soil Quality Index (SQI) with statistical applications in the form of Pearson Correlation Analyze and Principal Component Analysis (PCA). Analysis of the main components will produce PC data (Principal Component) or the main component. This PC data will be used to determine the Minimum Data Set (MDS) for the quality soil. Selected Principal Components are that have eigenvalues $\geq 1$ (Cantu et al. 2009). From each selected PC, the highest values are taken, then it will be used as the weight index of the indicator in calculating the land quality index. This study PC1 to PC3 which is a PC that meets the requirements to become a data set with cumulative $84.3 \%$, meaning that from the 8 indicators used to determine the Soil Quality Index of PC 1 to PC 3 (N-total, pH, available, Respiration, Organik Carbon, Base Saturation, Total Colony and Biomass have been able to represent $84.3 \%$ data. The results of MDS analysis using PCA can be seen in (Table 4) 
Table 4. Principal Component Analyze of soil characteristic on the rice field

\begin{tabular}{|c|c|c|c|}
\hline Eigenvalue $^{a}$ & 6,8848 & 2,0596 & 1,1724 \\
\hline Proportion $^{\mathrm{b}}$ & 0,574 & 0,172 & 0,098 \\
\hline Cumulative $^{c}$ & 0,574 & 0,745 & 0,843 \\
\hline \multicolumn{4}{|c|}{ Eigenvectors $^{\mathrm{d}}$} \\
\hline Variable & $\mathrm{PC}^{\mathrm{e}}$ & $P C 2^{f}$ & $\mathrm{PC}^{\mathrm{g}}$ \\
\hline Capacity Exchange Cation & 0,221 & $-0,49$ & 0,143 \\
\hline Total Nitrogen & 0,322 & 0,183 & $-0,171$ \\
\hline Bulk Density & 0,043 & 0,051 & 0,263 \\
\hline Available P & 0,361 & 0,088 & $-0,012$ \\
\hline Exchangeable Al & $-0,27$ & 0,097 & $-0,427$ \\
\hline Respiration & $\mathbf{0 , 3 1 7}$ & 0,185 & $-0,228$ \\
\hline Organic Carbon & $\mathbf{0 , 3 7}$ & $-0,083$ & $-0,043$ \\
\hline $\mathrm{pH}$ & 0,265 & 0,386 & $-0,326$ \\
\hline Available K & 0,248 & $-0,374$ & 0,179 \\
\hline Base Saturation & 0,064 & 0,328 & 0,706 \\
\hline Total Colony & 0,355 & $-0,11$ & $-0,083$ \\
\hline Carbon Biomass & $\mathbf{0 , 3 7 7}$ & 0,007 & 0,041 \\
\hline
\end{tabular}

${ }^{a}$ Boldface eigenvalues correspond to the PCs examined for the index.

${ }^{b}$ Boldface proportion is against the influence of the variable value on the Minimum Data Set

${ }^{c}$ Boldface cumulative the sum of the proportion up to the highest value has a value of 1

${ }^{\mathrm{d}}$ Boldface factor loadings are considered highly weighted and include in the Minimum Data Set

e Boldface PC1 (Principal Component 1)

${ }^{\mathrm{f}}$ Boldface PC2 (Principal Component 2)

${ }^{\mathrm{g}}$ Boldface PC3 (Principal Component 3)

The indicators used as MDS soil quality are determined with the highest value in each PC that has been adjusted based on the longest plot and predetermined criteria (PC1 to PC3). The indicator with the highest value on PC1 is N-total, Available, Respiration, Organic C, Total Colony, and Carbon Biomass get the proportion per an analysis of $9.57 \%$ because it correlates with each other. PC2 consists of $\mathrm{pH}$ which has a proportion of $17.2 \%$. Base Saturation on PC3 has a proportion of 9.8\%. Determining Soil Quality Index is obtained from the selected $\mathrm{PC}$ indicator value to find the index weight value (Wi), where Wi is the proportion divided by cumulative results can be seen in (Table 5). The results of the weighting of the index are used to find the Soil Quality Index (SQI) by multiplying the scoring of the selected MDS analysis. 
Table 5. Weight Index Calculation of Minimum Data Set

\begin{tabular}{cccc}
\hline Minimum Data Set & Proportion & Cumulative & Weight Index $^{a}$ \\
\hline Total Nirogen & 0,096 & 0,844 & 0,113 \\
Available P & 0,096 & 0,844 & 0,113 \\
Respiration & 0,096 & 0,844 & 0,113 \\
Organic Carbon & 0,096 & 0,844 & 0,113 \\
pH & 0,172 & 0,844 & 0,204 \\
Total Colony & 0,096 & 0,844 & 0,113 \\
Carbon Biomass & 0,096 & 0,844 & 0,113 \\
Base Saturation & 0,098 & 0,844 & 0,116 \\
\hline
\end{tabular}

${ }^{a}$ Weight index was obtained from the proportion divided by cumulative

Soil quality scoring based on Balittan (2005) can be seen in (Table 6). The results obtained from the calculation of the soil quality index are then classified according to (Cantu et al. 2009). Class of soil quality is divided into very good, good, medium, low and very low. Calculation of the Soil Quality Index (SQI) can be seen in (Table 7). Obtained from scoring, the minimum data set we can analyze consists of base saturation, total nitrogen, available $\mathrm{P}$, respiration, organic carbon having a higher scoring value in organic processing compared to semi-organic and inorganic.

Table 6. Scoring of Minimum Data Set

\begin{tabular}{lcccccccccc}
\hline \multirow{2}{*}{ No } & \multirow{2}{*}{ Minimum Data Set } & \multicolumn{1}{c}{ Scoring } \\
\cline { 2 - 10 } & 1 & 2 & 3 & 4 & 5 & 6 & 7 & 8 & 9 \\
\hline 1 & Base Saturation & 1 & 2 & 3 & 2 & 2 & 2 & 2 & 1 & 2 \\
2 & Total Nitrogen & 3 & 3 & 3 & 3 & 3 & 3 & 3 & 2 & 2 \\
3 & Available P & 1 & 1 & 1 & 1 & 1 & 1 & 1 & 1 & 1 \\
4 & Respiration & 2 & 2 & 2 & 2 & 1 & 1 & 1 & 1 & 1 \\
5 & Organic Carbon & 3 & 2 & 3 & 2 & 2 & 1 & 1 & 2 & 1 \\
6 & pH & 2 & 2 & 2 & 2 & 2 & 2 & 2 & 2 & 2 \\
7 & Total Colony & 2 & 2 & 2 & 2 & 2 & 2 & 2 & 2 & 2 \\
8 & Carbon Biomass & 1 & 1 & 1 & 1 & 1 & 1 & 1 & 1 & 1 \\
\hline
\end{tabular}

Sample 1-3 is organic paddy fields; 4-6 is semi-organic paddy fields; 7-9 is an organic paddy fields.

The results (Table 7) obtained the Weight Index or Wi results per analysis from the proportion analysis that appeared in the main component multiplied by the scoring. Scoring results of all analyzes at each point were then added and modified according to (Cantu et al. 2009). 
Table 7. Scoring Soil Quality Index On Rice Field With Several Systems

\begin{tabular}{|c|c|c|c|c|c|c|c|c|c|c|}
\hline \multirow{2}{*}{ No } & \multirow{2}{*}{$\begin{array}{c}\text { Minimum } \\
\text { Data Set } \\
\text { (MDS) }\end{array}$} & \multicolumn{9}{|c|}{ Soil Quality Index (SQI)* } \\
\hline & & 1 & 2 & 3 & 4 & 5 & 6 & 7 & 8 & 9 \\
\hline 1 & $\begin{array}{c}\text { Base } \\
\text { Saturation }\end{array}$ & 0,12 & 0,23 & 0,35 & 0,23 & 0,23 & 0,23 & 0,23 & 0,12 & 0,23 \\
\hline 2 & $\begin{array}{c}\text { Total } \\
\text { Nitrogen }\end{array}$ & 0,34 & 0,34 & 0,34 & 0,34 & 0,34 & 0,34 & 0,34 & 0,34 & 0,34 \\
\hline 3 & Available P & 0,11 & 0,11 & 0,11 & 0,11 & 0,11 & 0,11 & 0,11 & 0,11 & 0,11 \\
\hline 4 & Respiration & 0,23 & 0,23 & 0,23 & 0,23 & 0,11 & 0,11 & 0,11 & 0,11 & 0,11 \\
\hline 5 & $\begin{array}{l}\text { Organic } \\
\text { Carbon }\end{array}$ & 0,34 & 0,23 & 0,34 & 0,23 & 0,23 & 0,11 & 0,11 & 0,23 & 0,11 \\
\hline 6 & $\begin{array}{l}\text { Potensial } \\
\text { Hydrogen }\end{array}$ & 0,41 & 0,41 & 0,41 & 0,41 & 0,41 & 0,41 & 0,41 & 0,41 & 0,41 \\
\hline 7 & Total Colony & 0,23 & 0,23 & 0,23 & 0,23 & 0,23 & 0,23 & 0,23 & 0,23 & 0,23 \\
\hline 8 & $\begin{array}{l}\text { Biomass } \\
\text { Carbon }\end{array}$ & 0,11 & 0,11 & 0,11 & 0,11 & 0,11 & 0,11 & 0,11 & 0,11 & 0,11 \\
\hline & $\begin{array}{l}\text { Soil Quality } \\
\text { Index }\end{array}$ & 0,19 & 0,19 & 0,21 & 0,19 & 0,18 & 0,17 & 0,17 & 0,17 & 0,17 \\
\hline
\end{tabular}

*Soil Quality Index is the results from scoring $\mathrm{x}$ weight index

The results of the sample scoring in each analysis can be seen that the state of samples 12 and 3 which are included in organic conditions have a higher value of the Soil Quality Index. Larger Soil Quality Index Figures indicate a better value of data. Samples 45 and 6 which are included in semi-organic species have scoring that is between organic and non-organic. The transition of treatment between organic and non-organic has a positive impact on the quality of the soil. Inorganic treatments in samples 78 and 9 have lower scoring compared to organic and semi-organic samples. The use of excessive chemicals without the support of organic inputs will reduce the level of soil quality (Juarti 2016).

The results of the scoring in (Table 6) obtained results that affect base saturation, available $\mathrm{P}$, organic $\mathrm{C}$ and respiration which have higher scoring results in organic management compared to semi-organic and inorganic management. The addition of organic matter can increase the cations on the soil surface which can provide nutrients for plants (Marthews 2014).

Table 8. Soil Quality Index On Rice Field With Several Systems

\begin{tabular}{cccc}
\hline No & Paddy Field Sites & Soil Quality Index & Soil Quality Classificated \\
\hline 1 & Organic & 0,20 & Low \\
2 & Semi-organic & 0,18 & Very Low \\
3 & Inorganic & 0,17 & Very Low
\end{tabular}

The results of the calculation of soil quality where the quality index is obtained from the scoring calculation multiplied by the index weight. The results obtained by soil quality index on land that has organic treatment have higher soil quality. Organic treatments have a soil quality index of 0.20 (low). The semi-organic sample treatment has a moderate soil quality of around 0.18 (very low). Inorganic or inorganic treatments have a soil quality value of around 0.17 which has a very low value. According to Mujiyo et al. (2018), the use of paddy fields with organic systems will change the quality of the land to be better if done in the long term. The levels of organic $\mathrm{C}$-elements in organic systems have a higher value that can affect the number of microbes, $\mathrm{C}$ microbial biomass and microbial respiration which can increase biological activity to improve soil quality. The difference in management in the Mangunharjo rice field, Jatipurno has a significant difference after the T-test can be concluded that organic management affects better soil quality improvement with a p-value of 0.002 with inorganic and semi-biological management with a p-value of 0.010 . 


\section{Conclusions}

The quality of paddy soil in Mangunharjo Village managed organically has better soil quality compared to semi-organic and inorganic management with soil quality index values respectively $0.20,0.17$ and 0.15 . Biological indicators which include respiration, microbial biomass, and total colonies can be used in determining the paddy soil quality index in Mangunharjo Village, Jatipurno District. Rice production using organic rice systems over for more than 6 years has a lower yield compared to the management of semi-organic and inorganic rice systems.

\section{Acknowledgment}

This study was supported by the Ministry of Research, Technology and Higher Education, Republic of Indonesia, and Universitas Sebelas Maret, Surakarta.

\section{References}

Acosta-Martínez V., Cruz L., Sotomayor-Ramírez D. \& Pérez-Alegría L. (2007). Enzyme activities as affected by soil properties and land use in a tropical watershed. Applied Soil Ecology, 35, 35-45. https://doi.org/10.1016/j.apsoil.2006.05.012

Andrews, S. S., D. L. Karlen \& J. P. Mitchell. (2002). A comparison of soil quality indexing methods for vegetable production systems in Northern California. Agriculture, Ecosystem and Environment, 90, 25-45. https://doi.org/10.1016/S01678809(01)00174-8.

Arekhi S., Heydari M. \& Pourbabaei H. (2010). Vegetation Environmental Relationships and Ecological Species Groups of the Ilam Oak Forest Landscape, Iran, Caspian Journal of Environment Science, 8, 115-125. https://www.researchgate.net/publication/267993469

Balittan. (2005). Petunjuk teknis analisis kimia tanah, tanaman, air dan pupuk, Balai Penelitian tanah. Edited by B. H. Prasetyo, dan Djoko Santoso \& Ladiyani Retno W. Bogor. https://doi.org/10.1007/s13398-014-0173-7.2.

BPS Wonogiri. (2018). 'Halaman untuk cover hitam putih', in Sularto, S.St \& MT (eds) Kecamatan Jatipurno dalam angka 2018. Wonogiri. Available at: https://wonogirikab.bps.go.id

Brady N. \& Weil R. (2008). The Nature and Properties of Soils. Pearson Perntice Hall, New Jersey.

Brejda, J. I., T. B. Moorman, D. L. Karlen \& T. H. Dao. (2000). Identification of regional soil quality factors and indicators of central and southern high plains, Soil Science Society of America Journal, 64, 2115-24. doi:10.2136/sssaj2000.6462115x

Breure A.M., Mulder C., Römbke J. \& Ruf A. (2005) Ecological classification and assessment concepts in soil protection. Ecotox. Envir. Saf, 62, 2005. https://doi.org/10.1016/j.ecoenv.2005.03.025

Cantu, M. P. Becker A., Bedano J. C. \& Schiavo H. F. (2009). Disease surveillance using a hidden Markov model, BMC Medical Informatics and Decision Making, 9(1), 173-178. https://doi.org/10.1186/1472-6947-9-39.

Chandel, S., Hadda, M. S. \& Mahal, A. K. (2018). Soil quality assessment through minimum data set under different land uses of submontane Punjab, Communications in Soil Science and Plant Analysis. Taylor \& Francis, 49(6), 658-674. https://doi.org/10.1080/00103624.2018.1425424

Chaudhary, S., Dheri, G. S. \& Brar, B. S. (2017). Long-term effects of NPK fertilizers and organic manures on carbon stabilization and management index under rice-wheat cropping system, Soil and Tillage Research. Elsevier B.V., 166, 59-66. https://doi.org/10.1016/j.still.2016.10.005.

Chan K.Y. \& Barchia I. (2007). Soil compaction controls the abundance, biomass and distribution of earthworms in a single dairy farm in south-eastern Australia, Soil and Tillage Research, 94, 75-82. https://doi.org/10.1016/j.still.2006.07.006

Chen, X., Liu M., Kuzyakov Y., Li W., Liu J., Jiang C. \& Wu M., Li Z. (2018). Incorporation of rice straw carbon into dissolved organic matter and microbial biomass along a 100 -year paddy soil chronosequence, Applied Soil Ecology. Elsevier, 130(January), 84-90. https://doi.org/10.1016/j.apsoil.2018.06.004.

Darlita RR, Joy B \& Sudirja R, (2017). Analyse of soil chemical properties in the encriment of soil palm production on sandy soil at Selangkun oil palm plantation. Jurnal Agrikultura, 28(1), 15-20. https://doi.org/10.24198/agrikultura.v28i1.12294

Dengiz, O. (2019). Soil quality index for paddy fields based on standard scoring functions and weight allocation 
method. Archives of Agronomy and Soil Science. Taylor \& Francis, $0(0), \quad 1$. https://doi.org/10.1080/03650340.2019.1610880.

Dinesh R., Ghoshal Chaudhuri S., Ganeshamurthy A.N. \& Dey C. (2003). Changes in soil microbial indices and their relationships following deforestation and cultivation in wet tropical forests. Applied Soil Ecology, 24, 17-26. https://doi.org/10.1016/S0929-1393(03)00070-2

Doran, J. W. \& Parkin, T. B. (1994). Defining an assesing soil quality. Defining Soil Quality for a Sustainable Environment, 3-21, https://doi.org/10.2136/sssaspecpub35.c1

Doran JW \& Jones AJ. (1996). Methods for assessing soil quality. Soil Science Society of America Special Publication, No: 49. Soil Science Society of America, Inc. Madison, Wisconsin, USA. https://doi.org/10.2136/sssaspecpub49.frontmatter

Doran J.W. \& Zeiss M.R. (2000). Soil health and sustainability: managing the biotic component of soil quality, Applied Soil Ecology, 15, 3-11. https://doi.org/10.1016/S0929-1393(00)00067-6

Fernandes JC, Gamero CA \& Rodrigues JGLMirás-Avalos, J. M. (2011). Determination of the quality index of a Paleudult under sunflower culture and different management systems. Soil Tillage Res, 112, $167-74$. https://doi.org/10.1016/j.still.2011.01.001

Gençtan T. (2009). Problems of rice production in Turkey I. National Rice Symposium Tekirdağ, Turkey. Turkish.

Gulser Coskun. (2004). A Comparison of Some Physical and Chemical Soil Quality Indicators Influenced by Different Crop Species. Pakistan Journal of Biological Sciences, 7(6), 905-911. http://docsdrive.com/pdfs/ansinet/pjbs/2004/905-911.pdf

Hadi, M., Soesilohadi Hidayat \& Wagiman FX. (2014). Pertanian organik suatu alternatif pengelolaan ekosistem sawah yang sehat, alami dan ramah lingkungan, Buletin Anatomi dan Fisiologi, 22(1), $72-77$. https://doi.org/10.14710/baf.v22i1.7811

Islam K.R. \& Weil R.R. (2000). Land use effects on soil quality in a tropical forest ecosystem of Bangladesh. Agriculture, Ecosystems and Environment, 79, 9-16. https://doi.org/10.1016/S0167-8809(99)00145-0

Juarti. (2016). Analisis indeks kualitas tanah andisol pada berbagai penggunaan lahan di desa Sumber Brantas, Kota Baru. Jurnal Pendidikan Geografi, 21(2), 58-71. http://dx.doi.org/10.17977/jpg.v21i2.5907

Karlen, D. L. (1997). Soil Quality: A Concept, Definition \& Framework for Evaluation (A Guest Editorial). Soil Science Society of America Journal, 61(1), 4. https://doi.org/10.2136/sssaj1997.03615995006100010001x.

Kouamé F.N., Bongers F., Poorter L. \& Traoré D. (2004). Climbers and logging in the Forêt Classée du HautSassandra, Côte-d'Ivoire, Forest Ecology and Management, 194, 259-268. https://doi.org/10.1016/j.foreco.2004.02.029

Larson WE \& Pierce FJ. (1994). The dynamics of soil quality as a measure of sustainable management. In: Doran, JW (Ed.), Defining Soil Quality for a Sustainable Environment. Soil Science Society of America Special Publication No. 35. Soil Science Society of America, Inc. Madison, Wisconsin, USA

Liu Z, Zhou W, Shen J, Li S \& Ai C. (2014). Soil quality assessment of yellow clayey paddy soils with different productivity. Biol Fert Soils, 50, 537, https://doi.org/10.1007/s00374-013-0864-9.

Li P, Zhang T, Wang X \& Yu D. (2013). Development of biological soil quality indicator system for subtropical China, Soil Tillage Res, 126, 112-18. https://doi.org/10.1016/j.still.2012.07.011

Martinez-Salgado, M. M., Gutierrez-Romero, V. \& Jannsens, M; Ortega-Blu, R. (2010). Biological soil quality indicators: a review. Current Research, Technology and Education Topics in Applied Microbiology and Microbial Biotechnology. (2000), 319-328. https://www.researchgate.net/publication/285738755

Matthews, J. A. (2014). Base Saturation. Encyclopedia of Environmental Change. https://doi.org/10.4135/9781446247501.n361.

Marzaioli R, D’Ascoli R, De Pascale RA \& Rutigliano FA. (2010). Soil quality in a Mediterranean area of southern Italy as related to different land use types, Appl Soil Ecol, 44, $205-12$. https://doi.org/10.1016/j.apsoil.2009.12.007

McCauley A. (2018). Soil pH and organic matter. Nutrient Manajement Module no 8. Montana State University. http://landresources.montana.edu/nm/documents/NM8.pdf

Mujiyo., Sunarmianto B.H., Hanudin E., Widada J. \& Syamsyiah J. (2018). The effect of organic paddy field 
system to soil properties. IOP Conference Series: Earth and Environmental Science, 122(1), https://doi.org/10.1088/1755-1315/122/1/012023.

Mustikaningrum, I. A., Supriyadi, Herawati A., Purwanto P. \& Sumani S. (2018). Soil quality assessment in organic and non organic paddy fi elds in Susukan, Indonesia, Bulgarian Journal of Agricultural Science, 24(5), 777-784. http://dx.doi.org/10.17951/pjss.2018.51.2.173

Nwaichi, E.O. \& Chuku, L.C. (2017). Biological Soil Quality Indicators and Conditioners in a Plant-Assisted Remediation of Crude Oil Polluted Farmland, Journal of Environmental Protection, (8), 1622-1635. https://doi.org/10.4236/jep.2017.813100

Oladele, S. O., Adeyemo, A. J. \& Awodun, M. A. (2019). Influence of rice husk biochar and inorganic fertilizer on soil nutrients availability and rain-fed rice yield in two contrasting soils. Geoderma, Elsevier, 336(August 2018), 1-11. https://doi.org/10.1016/j.geoderma.2018.08.025.

Primadani, P., Utomo, S. \& Supriyadi. (2010). Pemetaan kualitas tanah pada beberapa penggunaan lahan di Kecamatan Jatipuro Kabupaten Karanganyar, Jurnal Ilmu Tanah dan Agroklimatologi, 7(2), 83-96. Available at: http://eprints.uns.ac.id/7211/

Qi Y, Darilek JL, Huang B, Zhao Y, Sun W \& Gu Z. (2009). Evaluating soil quality indices in an agricultural region of Jiangsu Province, China. Geoderma, 149, 325-34. https://doi.org/10.1016/j.geoderma.2008.12.015

Reeves, D. W. (1997). The role of soil organic matter in maintaining soil quality in continuous cropping systems, Soil and Tillage Research, 43(1-2), 131-167. https://doi.org/10.1016/S0167-1987(97)00038-X.

Rezaei, S. A., R. J. Giles \& S. S. Andrew. (2006). A minimum data set for assessing soil quality in rangeland, Geoderma, 126, 229-34. https://doi.org/10.1016/igeoderma.2006.03.021.

Riches D, Porter I.J., Oliver D.P., Bramly R. G. V., Rawnsley B., Edwards J. \& White R.E. (2013). Review: soil biological properties as indicators of soil quality in Australian viticulture, Australian Journal of Grape and Wine Research, (19), 311-323. https://doi.org/10.1111/ajgw.12034

Sari M. N., Sudarsono \& Darmawan. (2017). Effect of organic matter on phophate availability in soils rich of al dan fe, Buletin Tanah dan Lahan, 1(1), 65-71. https://doi.org/10.1590/1413-70542016404023016

Sezer İ \& Dengiz O. (2014). Application of multi-criteria decision making approach for rice land suitability analysis in Turkey, Turk J Agric For, 38, 926-934. https://doi.org/10.3906/tar-1405-85

Sitepu, R. B., Anas, I. \& Djuniwati, S. (2017). Pemanfaatan jerami sebagai pupuk organik untuk meningkatkan pertumbuhan dan produksi padi (Oryza sativa ) utilization of straw as organic fertilizer to increase growth and production of rice (Oryza sativa), Buletin Tanah dan Lahan, 1(1), 100-108. https://journal.ipb.ac.id/index.php/btanah/article/view/17698/12672

Sufardi, Martunis, L. \& Muyassir. (2017). Pertukaran Kation pada Beberapa Jenis Tanah di Lahan Kering Kabupaten Aceh Besar Provinsi Aceh (Indonesia). in Prosiding Seminar Nasional Pascasarjana (SNP) Unsiyah, 45-53. http://jurnal.unsyiah.ac.id/SNP-Unsyiah/article/view/6869

Sukristiyonobowo, Purwanto, B. H. \& Husen, E. (2015). Soil properties under organic versus inorganic vegetable farming systems in Bogor district, Indonesian Soil and Climate Journal, 39(1), 19-24. http://ejurnal.litbang.pertanian.go.id/index.php/jti/article/view/6216/5374

Supriyadi, S, Purwanto, Sarijan A. Mekiuw Y., Usiatik R. \& Prahesti R. R. (2017). The assessment of soil quality at paddy fields in Merauke, Indonesia, Bulgarian Journal of Agricultural Science, 23(3), 443-448. https://www.researchgate.net/publication/318225326

Surekha, K. (2013). Evaluation of organic and inorganic rice production systems for their productivity, profitability, grain quality and soil health, Agrotechnology, 01(S11). https://doi.org/10.4172/2168-9881.s11-006.

Susilawati, Mustoyo, Budhisurya E., Anggono R.C.W. \& Simanjuntak B. H. (2017). Analisis Kesuburan tanah dengan indikator mikroorganisme tanah pada berbagai sistem penggunaan lahan di Plateau Dieng, Agric, 25(1), 64. https://doi.org/10.24246/agric.2013.v25.i1.p64-72.

Wahyuni, S., Rianto S., Muanisah U. \& Setyanto P. (2016). Pemanfaatan pupuk organik untuk meningkatkan populasi bakteri dan produksi tanaman padi gogorancah. Proceeding Biology Education Conference, Biology, Science, Enviromental \& Learning, 13(1), 752-756. Available at: https://jurnal.uns.ac.id/prosbi/article/view/5902 
Zhao, J., Ni T., Li J., Lu Q., Fang Z., Huang Q., Zhang R., Li R., Shen B. \& Shen Q. (2016). Effects of organic-inorganic compound fertilizer with reduced chemical fertilizer application on crop yields, soil biological activity and bacterial community structure in a rice-wheat cropping system, Applied Soil Ecology, Elsevier B.V., 99, 1-12. https://doi.org/10.1016/j.apsoil.2015.11.006

\section{Copyrights}

Copyright for this article is retained by the author(s), with first publication rights granted to the journal.

This is an open-access article distributed under the terms and conditions of the Creative Commons Attribution license (http://creativecommons.org/licenses/by/3.0/). 